TAPROBANICA, ISSN 1800-427X. May, 2020. Vol. 09, No. 01: pp. 71-82, pls. 25-29. (C) Research Center for Climate Change, University of Indonesia, Depok, Indonesia www.taprobanica.org

\title{
A NEW DIMINUTIVE DAY GECKO SPECIES OF THE GENUS Cnemaspis STRAUCH, 1887 (REPTILIA: GEKKONIDAE) FROM PILIKUTTUWA, NEAR THE CAPITAL OF SRI LANKA
}

\author{
A.A. Thasun Amarasinghe $e^{1,3}$ \& Suranjan Karunarathna ${ }^{2}$ \\ ${ }^{1}$ Research Center for Climate Change, University of Indonesia, Gd. PAU Lt. 8.5, Kampus UI, Depok 16424, \\ Indonesia \\ ${ }^{2}$ Nature Explorations \& Education Team, No: B-1 / G-6, De Soysapura Flats, Moratuwa 10400, Sri Lanka \\ ${ }^{3}$ Association of Asian Herpetology (Asosiasi Herpetologi Asia), Jl. BSD Bintaro No. 88, Pondok Aren 15228, \\ Tangerang Selatan, Indonesia \\ ${ }^{1}$ Corresponding author. E-mail: thasun@rccc.ui.ac.id
}

\begin{abstract}
We investigated diminutive day geckos of the genus Cnemaspis in Sri Lanka, and based on morphological evidence, a new species belonging to the $C$. podihuna complex is described herein. The new species occurs in lowland wetzone (alt. $50 \mathrm{~m}$ a.s.1.) forests and adjacent human habitations which have a dense tree cover in Gampaha District, near Colombo, the capital of Sri Lanka. We also provide a key for this and previously recognized species from Sri Lanka, based on collected material and literature.
\end{abstract}

Key words: Colombo, Cnemaspis podihuna; Cnemaspis tropidogaster; urban biodiversity, taxonomy

\section{Introduction}

The genus Cnemaspis Strauch, 1887 is speciesrich and geographically widespread in Africa, and South \& Southeast Asia, with many new species having recently been discovered from Sri Lanka (Karunarathna et al. 2019a-c, Batuwita et al. 2019, de Silva et al. 2019, Karunarathna \& Ukuwela 2019). Interestingly, the genus was shown to be polyphyletic, although Sri Lankan species fall into two broad divergent groups among the South Asian lineage: the podihuna and kandiana clades (Agarwal et al. 2017, Karunarathna et al. 2019b).
Before 2007, the genus Cnemaspis in Sri Lanka comprised only four species: $C$. kandiana (Kelaart, 1852), C. scalpensis (Ferguson, 1877), $C$. tropidogaster (Boulenger, 1885), and $C$. podihuna Deraniyagala, 1944. Recent phylogenetic studies placed $C$. kandiana and $C$. tropidogaster in the kandiana clade, while $C$. scalpensis and $C$. podihuna were placed in podihuna clade (Agarwal et al. 2017, Karunarathna et al. 2019b). Previously, both $C$. scalpensis and $C$. podihuna were considered as widely distributed species complexes (Wickramasinghe 2006, Karunarathna et al. 
2011), and several species were discovered from these complexes within the podihuna clade: Wickramasinghe (2006) and Bauer et al. (2007) described two species: $C$. ranwellai and $C$. gemunu respectively. However the former species was synonymised with $C$. scalpensis by Manamendra-Arachchi et al. (2007). Wickramasinghe and Munindradasa (2007) described two species: $C$. alwisi and $C$. molligodai. Simltaneously ManamendraArachchi et al. (2007) also described another two species: C. phillipsi and C. punctata. Then, Vidanapathirana et al. (2014) and Wickramasinghe et al. (2016) described $C$. rammalensis and $C$. rajakarunai respectively. Alhough the identity of the holotype of $C$. podihuna has long been disputed (Wickramasinghe \& Munindradasa 2007, Manamendra-Arachchi et al. 2007), it was recently rediscovered and redescribed (Amarasinghe \& Bauer 2009, Amarasinghe \& Campbell 2016). Subsequently Batuwita \& Udugampala (2017) described C. kandambyi. Karunarathna et al. (2019a,b) described $C$. nilgala, C. hitihami (sic), C. kohukumburai, and subsequently de Silva et al. (2019) described $C$. godagedarai. Finally, Karunarathna \& Ukuwela (2019) described one more species, C. anslemi. Therefore, based on Karunarathna et al. (2019b), the podihuna clade currently comprises 15 species in Sri Lanka, and Karunarthna et al. (2019b) further identified three groups (subclades) within the podihuna clade: currently (1) the scalpensis group consists of five species (C. anslemi, C. gemunu, C. godagedarai, C. phillipsi, $C$. scalpensis), (2) the podihuna group consists of three species (C. kandambyi, $C$. molligodai, $C$. podihuna), and (3) the alwisi group consists of seven species (C. alwisi, $C$. hitihamii, $C$. kohukumburai, $C$. nilgala, $C$. punctata, C. rajakarunai, C. rammalensis).

During museum reference work in 2015, we found three specimens of unknown Cnemaspis among the collections of NMSL, along with the rediscovery of Cnemaspis tropidogaster (see Amarasinghe et al. 2016). These specimens were collected from Pilikuttuwa and Maligatenna in Gampaha District, Western Province, and provisionally identified as $C$. molligodai. Although Amarasinghe et al. (2016) noted the peculiarity of finding Cnemaspis molligodai from low altitudes of the wet zone, they had not hitherto compared them to the types of all Sri Lankan Cnemaspis. Therefore, here we sought to compare those specimens to confirm their identity. Upon closer examination, it is clear that these specimens included a distinct unnamed species belonging to the podihuna group, which we describe as a new species.

\section{Material and methods}

The type series is currently stored in $70 \%$ ethanol. We examined the type specimens representing all the Sri Lankan species of the podihuna clade, including available voucher specimens; the examined specimens are listed in Appendix I. Assignment of unidentified specimens to species was based on the presence of shared morphometric and meristic characters. Museum acronyms follow Uetz et al. (2019). Specimens were examined at the British Museum, London, UK (BMNH); National Museum of Sri Lanka, Colombo, Sri Lanka (NMSL); and Wildlife Heritage Trust, Colombo, Sri Lanka (WHT). The WHT collection has now been deposited at NMSL, but is currently uncatalogued.

When diagnosing and describing the new species, we scored specimens for the same morphological characters used in recent descriptions of members of the podihuna clade (e.g., Manamendra-Arachchi et al. 2007, Amarasinghe \& Campbell 2016, and Karunarathna et al. 2019b). Measurements were obtained from the left side of the body to the nearest $0.1 \mathrm{~mm}$ using Mitutoyo digital calipers under a Leica-Wild M3Z dissecting microscope.

We measured snout-vent length (SVL, from tip of snout to anterior margin of vent), axillagroin length (from the posterior margin of the forelimb at its insertion point on the body to the anterior margin of the hind limb at its insertion point on the body), head length (from posterior edge of mandible to tip of snout); head width (maximum width of head at the angle of the jaws), orbit diameter (the greatest diameter of the orbit); tympanum-eye length (from posterior border of orbit to anterior border of tympanum), snout length (from anterior border of orbit to tip of snout), eye-nostril length (from anterior border of orbit to posterior border of nostril), interorbital width (shortest distance between dorso-medial margins of orbits), tympanum diameter (greatest diameter of tympanum), internarial length (shortest distance between dorsal margins of nostrils), brachium length (on the dorsal surface from the axilla to the inflection of the flexed elbow), antebrachium length (on the dorsal surface from the posterior margin of the elbow while flexed to the 
inflection of the dorsiflexed wrist), palm length [from wrist (carpus) to distal tip of longest finger], finger lengths I-V (from tip of claw to the nearest fork), thigh length (from the anterior margin of the hind limb at its insertion point on the body to the knee while flexed), shank length (from the posterior surface of the knee while flexed to the base of the heel), foot length (from heel to tip of longest toe), toe lengths I-V (from tip of claw to the nearest fork), and tail length (from tip of tail to posterior margin of vent).

We counted supralabial and infralabial scales (from the gape of mouth to the rostral and mental scales, respectively), ventrals (all the scales from the mental to the last scale bordering the vent along the midventral line), ventral scale rows (the number of longitudinal ventral scle rows at midbody), midbody scale rows (total number of longitudinal scale rows around the midbody including both dorsal and ventral sides). We counted subdigital lamellae on each finger and toe $\mathrm{I}-\mathrm{V}$, from the first proximal enlarged scansor wider than the width of the largest palm scale to the distal-most lamella (excluding the claw sheath) at the base of the claw. We also counted the total number of precloacal and femoral pores, and assessed their orientation. Number of non-pored scales (interfemoral scales) between pore-bearing femoral rows on both femurs was counted.

We measured the degree and arrangement of body and tail tuberculation texture (homogeneous or heterogeneous), spinous scales on flanks, and the relative size and morphology of the subcaudal scales. We evaluated the texture of the scales on the ventral surface of brachium and antebrachium. We sexed specimens by examining everted hemipenes or hemipenial bulges at the tail base. To view some small characters such as keeling of the ventrals, we applied the reversible stain methylene blue in 70\% ethanol, following Amarasinghe et al. (2015).

The conservation status and risk of extinction of the species was evaluated using the IUCN Standards and Petitions Subcommittee (IUCN 2019) guide: applying the criteria B2-b (iii).

\section{Results}

We present comparative morphometric and meristic data obtained for the type specimens (Tables 1). Statistically informative tests could not be performed because of the small sample sizes. Nonetheless, interspecific comparisons of morphological and meristic characters (discrete or non-discrete) revealed a suite of characters that distinguish the new species from congeners (Table 2). In the diagnosis and identification keys, we summarize the differences between Sri Lankan Cnemaspis species.

\section{Taxonomy}

Cnemaspis manoae sp. nov.

(Figs. 1-6, Tables 1-3)

Holotype. Adult male, NMSL 2019.10.01, SVL $25.3 \mathrm{~mm}$, collected from Pilikuttuwa ( $7^{\circ} 03^{\prime} 28.14 " \mathrm{~N}, 80^{\circ} 02^{\prime} 53.18^{\prime \prime} \mathrm{E}$; alt. 52 m a.s.l.), Gampaha District, Western Province, Sri Lanka, by Anslem de Silva on 22 November 2005.

Paratypes $(\boldsymbol{n}=2)$. Adult male, NMSL 2019.10.02, SVL $24.6 \mathrm{~mm}$; adult female, NMSL 2019.10.03, SVL $24.4 \mathrm{~mm}$; other details are the same as holotype. See Table 1 for morphometric and meristic characters, other morphological characters is same as holotype.

Diagnosis. The following combination of characters distinguishes the new species from all other congeners: adult males reaching $25.3 \mathrm{~mm}$ SVL, adult females reaching $24.4 \mathrm{~mm} \mathrm{SVL} ; 7$ or 8 supralabials; dorsal granules homogeneous, 119-126 paravertebral granules; four or five spines on flanks; throat, pectoral, and abdominal scales smooth; $117-121$ ventrals; five precloacal pores and nine femoral pores (per thigh) in males, no interfemoral scales; 79-83 midbody scales, $15-17$ ventral scale rows; 15 or 16 subdigital lamellae on fourth toe; subcaudals smooth, hexagonal shaped, median row of subcaudals greatly enlarged; the differences are summarized for geographically close congeners (Table 2) and for all Sri Lankan species in Karunarathna et al. (2019c, their Table 9).

Description of holotype. Characters of holotype followed, when appropriate, by those of paratypes in parenthesis. An adult male, 25.3 $\mathrm{mm}$ SVL (male paratype $24.6 \mathrm{~mm}$, female paratype $24.4 \mathrm{~mm}$ ); head moderately large, elongate, narrow, distinct from neck, its length $23.3 \%$ of SVL $(30.9 \%, 27.4 \%)$; head width $66.1 \%$ of head length $(56.6 \%, 62.7 \%)$ and $15.4 \%$ of SVL $(17.5 \%, 17.2 \%)$; snout elongate, its length $71.8 \%$ of head width $(72.1 \%, 69.0 \%)$ and greater than eye diameter (eye diameter $57.1 \%$ of eye-snout length [51.6\%, 51.7\%]); interorbital region broad; interorbital distance $49.1 \%$ of head length $(44.7 \%, 46.5 \%)$; eye large, 
its diameter $27.1 \%$ of head length $(21.0 \%$, $22.4 \%$ ); pupil rounded; ear-opening deep, oval; diameter of eyes smaller than eye to ear distance (eye diameter $51.6 \%$ of eye-ear distance $[48.5 \%, 46.9 \%])$; scales of snout smooth, larger than those of occipital region; scales of interorbital, superciliary, and gular regions granular; rostral scale partially divided by medial groove, postero-ventrally in contact with first supralabial, contacted posteriorly by two nasals and two subcircular supranasals; single internasal scale between supranasals; nostrils oval, dorsally orientated; three postnasals, lowest in broad contact with first supralabial; nasals in broad contact with first supralabial.

Mental subtriangular, elongate and lengthened posteriorly to level of first supralabial, wider than long, postero-laterally in contact with two enlarged postmentals; postmentals medially separated by single postmental scale; postmentals bordered posteriorly by three smooth scales on both sides, including medial scale; scales on throat smooth, juxtaposed; bluntly pointed scales on side of neck, similar in size to those at mid-dorsum; three scale rows separating orbit from supralabials at level of pupil; 7 supralabials; 7 infralabials $(8,8)$, decreasing in size towards angle of jaw.

Body slender, elongate; axilla-groin distance $37.5 \%$ of SVL $(37.5 \%, 41.8 \%)$; middorsal granules bluntly pointed, homogeneous, smooth; five spine-like tubercles on flank; dorsal scales at midbody smaller than ventrals at same level; paravertebral granules 122 (126, 119); pectoral and abdominal scales subequal in size, smooth, bluntly pointed, overlapped; ventral scales in 15 (17-15) rows across midbody, ventro-lateral scales on trunk bluntly pointed and smooth; no ventrolateral fold distinct; scales around midbody 81 (79-83); ventrals 117 (121, $119)$; five precloacal pores (5, absent in female) and nine femoral pores ( 9 , absent as female).

Arms moderately short; length of brachium $13.8 \%$ of SVL $(13.4 \%, 15.5 \%)$; length of antebrachium $14.6 \%$ of SVL $(13.0 \%, 15.9 \%)$; legs relatively long; shank length $19.4 \%$ of SVL $(21.1 \%, 20.1 \%)$; thigh short, its length $16.2 \%$ of SVL $(20.7 \%, 18.4 \%)$; dorsal scales on both arms and legs bluntly pointed and enlarged; ventral scales on brachium and antebrachium granular and smooth, scales on ventral surface of thigh bluntly pointed and smooth; digits elongate, slender, all bearing slightly recurved claws; subdigital lamellae entire, 16 on toe IV; inter- digital webbing absent; relative lengths of fingers and toes IV $>$ III $>$ V $>$ II $>$ I.

Tail complete; tail base swollen; no postcloacal spurs; dorsal scales on tail bluntly pointed and smooth; dorsal granules like scales on tail homogeneous and directed backwards; dorsal tail with 2-3 enlarged obtuse scales forming whorls; subcaudal scales at base small, bluntly pointed and smooth, distally enlarged; median subcaudal row enlarged and hexagonal.

Variation. See Table 1.

Coloration. In life, the holotype had a dorsal pattern of bright yellow vertebral markings on a uniform dark brown background color. The snout lighter brown, a dark brown streak along the canthus rostralis on each side of the head. Behind the eye, a sharp dark brown band until the shoulders; the neck had a bright yellow and black stripe, and a vertebral dark bright yellow stripe shading laterally. Arms and legs uniform light brown, antebrachium with pale cross stripes. The yellowish tail had ten bright yellow markings.

After 14 years in preservative, the yellow pigment has faded to reddish brown and the dark brown background color to grayish brown. The ventral body and head is mostly brownish fading to cream medially and on the chin, tail pale in colour. Venter cream, tail pale yellowish.

Etymology. The specific epithet is an eponym latinized as a noun in the genitive singular, honoring Mrs. Mano Kalupahana, the biology teacher of the first author at his senior high school, The Royal College, Colombo 7, Sri Lanka. The author expresses sincere appreciation for her remarkable generous teaching and advice, which encouraged the first author to study zoology, and marked the turning point in his becoming a taxonomist. Suggested

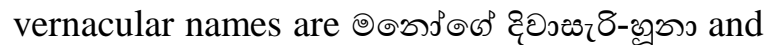
Mano's Day-gecko, in Sinhala and English, respectively.

Distribution and natural history. The new species occurs in at least three localities: Pilikuttuwa $\left(7^{\circ} 03^{\prime} 28^{\prime \prime} \quad \mathrm{N}, \quad 80^{\circ} 02^{\prime} 53^{\prime \prime}\right.$ E), Maligatenna $\left(7^{\circ} 04^{\prime} 04^{\prime \prime} \mathrm{N}, 80^{\circ} 03^{\prime} 50^{\prime \prime}\right.$ E) [see discussion], and Vaarana ( $7^{\circ} 06^{\prime} 12^{\prime \prime} \mathrm{N}, 80^{\circ} 04^{\prime} 27^{\prime \prime}$ E), Gampaha District, Western Province.

These forested areas are of lowland tropical rainforest vegetation (Gunatilleke \& Gunatilleke 1990) but the massive, rocky habitats and caves create a dry-mixed habitat. The core study area was approximately $2.5 \mathrm{~km} \times 1.5 \mathrm{~km}(\sim 500 \mathrm{ha})$, at an elevation range of approximately 40-160 $\mathrm{m}$ a.s.l. 


\section{Plate 25}

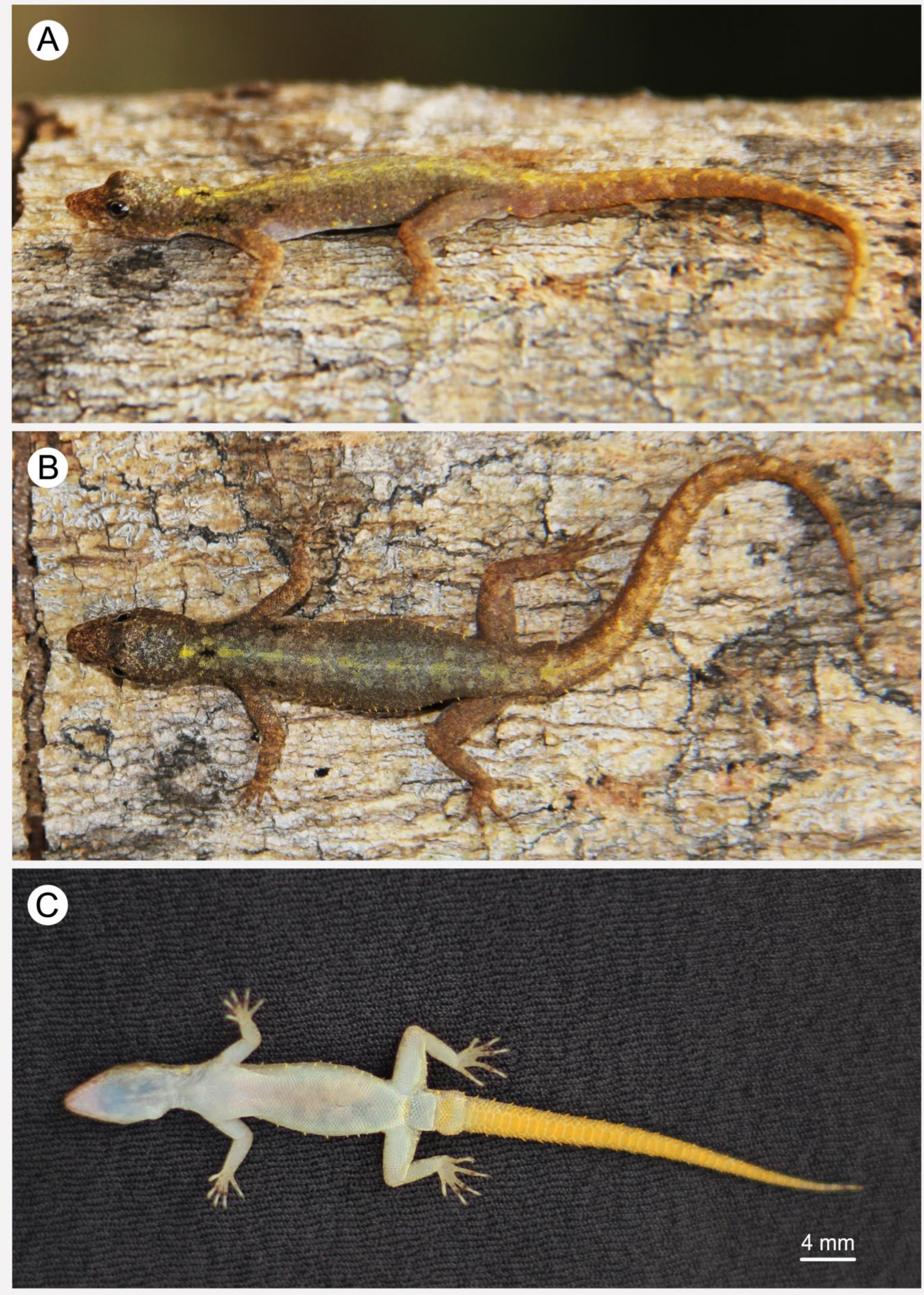

Figure 1. Cnemaspis manoae sp. nov. holotype in life (collected, NMSL 2019.10.01) (A) dorsolateral (B) dorsal, and $(\mathbf{C})$ ventral views. 


\section{Plate 26}

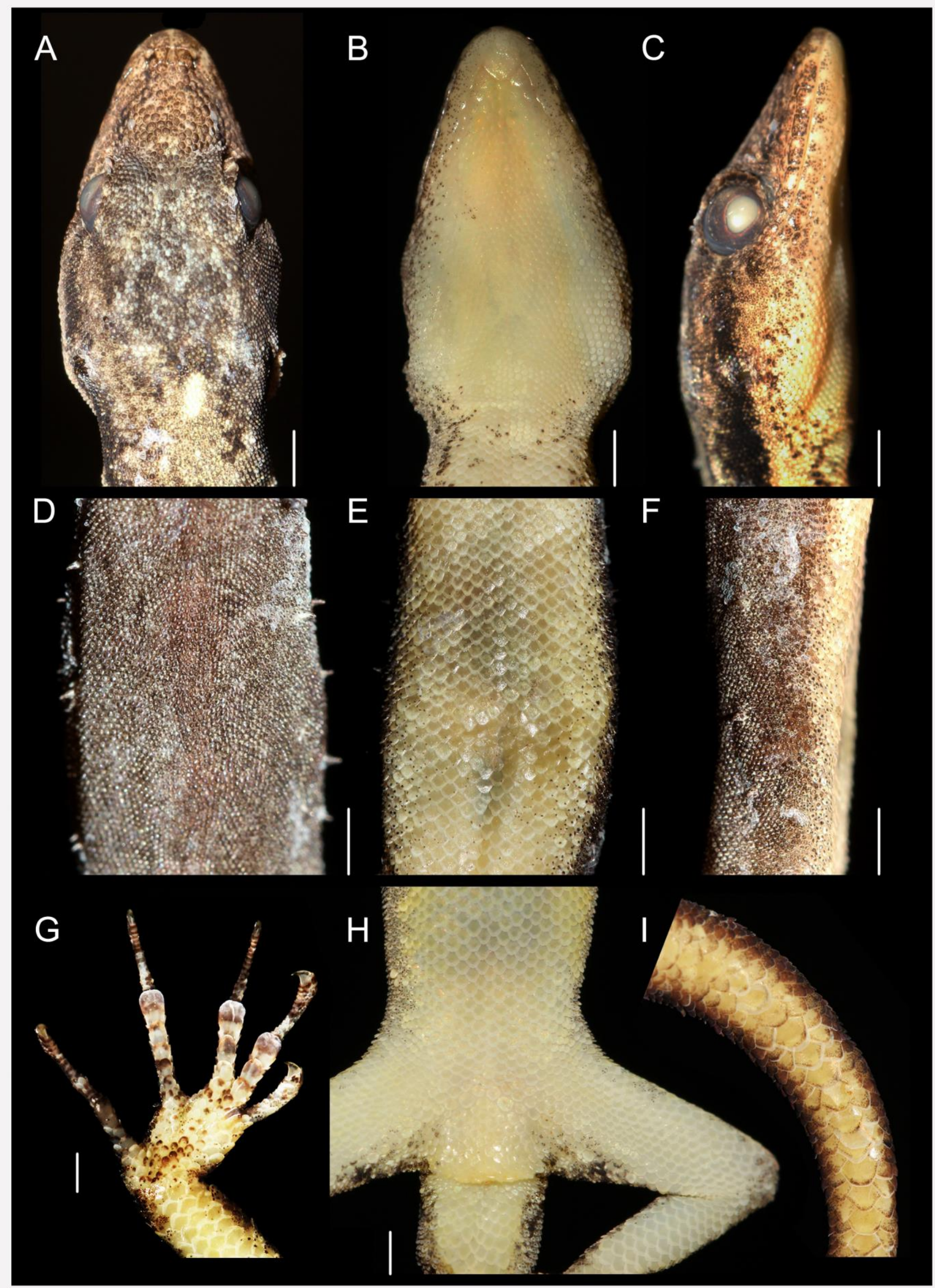

Figure 2. Cnemaspis manoae sp. nov. paratype (NMSL 2019.10.02) head in (A) dorsal view, (B) ventral view, (C) lateral view; midbody in (D) dorsal view, (E) ventral view, (F) lateral view; and ventral view of (G) foot \& toes, (H) cloacal area, and (I) tail (Scale: $1 \mathrm{~mm})$. 
Based on our observations in 2015, all individuals were found in dry, shaded, cool surfaces of large tree trunks, and on wattle and daub houses (Fig. 3). We observed this species from 5 different types of trees in the above forested areas. We did not observe any gravid females and eggs or juveniles. Usually 1-2 geckos (individuals per man-hour of search) were recorded at these three localities.

Conservation status. The application of the IUCN Red List criteria (2019) shows that $C$. manoae sp. nov. is Critically Endangered (CR) because it is restricted to an area of occupancy
$(\mathrm{AOO})<1 \mathrm{~km}^{2}$ and the extent of occurrence (EOO) is $<2 \mathrm{~km}^{2}$ in the wet zone [Applicable criteria is B2-b (iii)] assuming that the three fragmented sites documented here are the extent of the species' range. However, confirmation that the species does not occur in adjacent areas should be sought before a final determination on conservation status is made. See the maps (Figs. 4 \& 6) for known distribution. Surrounding habitats of the type locality are currently being destroyed by pineaple plantations invading the natural forests, and illegal logging inside the forest (Fig. 5).

Table 1. Morphometric (in $\mathrm{mm}$ ) and meristric character comparisons of holotype and paratypes of Cnemaspis manoae sp. nov.

\begin{tabular}{|c|c|c|c|}
\hline \multirow{3}{*}{ Character } & \multicolumn{3}{|c|}{ Cnemaspis manoae sp. nov. $(n=3)$} \\
\hline & \multicolumn{2}{|c|}{ male } & \multirow{2}{*}{$\begin{array}{c}\text { female } \\
\text { paratype } \\
(\text { NMSL 2019.10.03) }\end{array}$} \\
\hline & $\begin{array}{c}\text { holotype } \\
\text { (NMSL 2019.10.01) }\end{array}$ & $\begin{array}{c}\text { paratype } \\
\text { (NMSL 2019.10.02) }\end{array}$ & \\
\hline snout-vent length & 25.3 & 24.6 & 24.4 \\
\hline axilla-groin length & 9.5 & 9.1 & 10.2 \\
\hline head length & 5.9 & 7.6 & 6.7 \\
\hline head width & 3.9 & 4.3 & 4.2 \\
\hline orbit diameter & 2.6 & 2.9 & 2.7 \\
\hline tympanum-eye length & 3.1 & 3.3 & 3.2 \\
\hline snout length & 2.8 & 3.1 & 2.9 \\
\hline eye-nostril length & 1.9 & 2.1 & 2.1 \\
\hline interorbital width & 2.9 & 3.4 & 3.1 \\
\hline tympanum diameter & 0.6 & 0.7 & 0.7 \\
\hline internarial length & 1.5 & 1.4 & 1.6 \\
\hline brachium length & 3.5 & 3.3 & 3.8 \\
\hline antebrachium length & 3.7 & 3.2 & 3.9 \\
\hline palm length & 2.9 & 3.0 & 3.1 \\
\hline finger I-V lengths & $1.4,1.8,2.4,3.2,2.1$ & $1.5,1.7,2.5,3.0,2.2$ & $1.5,1.8,2.5,3.2,2.2$ \\
\hline thigh length & 4.1 & 5.1 & 4.5 \\
\hline shank length & 4.9 & 5.2 & 4.9 \\
\hline foot length & 3.1 & 3.1 & 3.2 \\
\hline toe $\mathrm{I}-\mathrm{V}$ lengths & $1.3,2.8,3.1,3.7,3.3$ & $1.4,3.1,3.3,3.9,3.6$ & $1.2,2.9,3.2,3.8,3.4$ \\
\hline tail length & 24.2 & 25.2 & 24.7 \\
\hline Supralabials (L/R) & 7,8 & 7 & 7 \\
\hline Infralabials (L/R) & 7 & 8 & 8,7 \\
\hline ventrals & 117 & 121 & 119 \\
\hline ventral scale rows & 15 & 17 & 15 \\
\hline midbody scale rows & 81 & 79 & 83 \\
\hline lamellae finger I-V & $8,11,12,13,12$ & $8,11,12,14,12$ & $8,11,12,14,12$ \\
\hline lamellae toe I-V & $9,11,14,16,13$ & $9,11,15,16,14$ & $10,12,14,16,14$ \\
\hline precloacal pores & 5 & 5 & absent \\
\hline femoral pores & 9 & 9 & absent \\
\hline
\end{tabular}

Comparison. Cnemaspis manoae sp. nov. is most similar to C. kandambyi, C. molligodai and $C$. podihuna, and its diagnostic chracters are listed in Table 2.

The new species is distinguished from Cnemaspis scalpensis (Ferguson, 1877); C. gemunu Bauer, de Silva, Greenbaum et al., 2007; C. phillipsi Manamendra-Arachchi, Batuwita \& Pethiyagoda, 2007; C. godagedarai de Silva, Bauer, Botejue et al., 2019; and C. anslemi Karunarathna \& Ukuwela, 2019 by having five precloacal pores ( $v s$ absent) and 9 
femoral pores ( $v s$ 11-16) in males. It further differs from $C$. scalpensis by having 119-126 paravertebral granules (vs 102-112), 4-5 flank spines (vs 9-11), 15-16 lamellae on fourth toe (19-21), and lacking interfemoral scales (vs 812); from C. gетипu by having 119-126 paravertebral granules (vs 79-93), 4-5 flank spines (vs 7-8), 15-16 lamellae on fourth toe (18-19), and lacking interfemoral scales (vs 1012); from $C$. phillipsi by having 117-121 ventrals (vs 128-143), 15-17 ventral scale rows (vs 18-25), 119-126 paravertebral granules (vs 86-93), 15-16 lamellae on fourth toe (17-19), and lacking interfemoral scales (vs 11-14); from C. godagedarai by having 117-121 ventrals (vs 133-137), 15-17 ventral scale rows (vs 21-23), 79-83 midbody scale rows (vs 98-102), 119126 paravertebral granules (vs 101-106), 15-16 lamellae on fourth toe (20-21), and lacking interfemoral scales ( $v s 8$ ); and from C. anslemi by having $117-121$ ventrals (vs 111-117), 15-17 ventral scale rows ( $v s$ 19-21), 79-83 midbody scale rows ( vs 87-91), 15-16 lamellae on fourth toe (20-21), and lacking interfemoral scales (vs 9-10).

The new species is also distinguished from Cnemaspis alwisi Wickramasinghe \& Munindradasa, 2007 in being smaller SVL 25.3 $\mathrm{mm}$ ( vs $40.4 \mathrm{~mm}$ ) and by having 117-121 ventrals ( vs 145-153), 15-17 ventral scale rows (vs 27-31), 79-83 midbody scale rows (vs 7178), 119-126 paravertebral granules (vs 89-97), 15-16 lamellae on fourth toe (17-21), five precloacal pores ( $v s$ absent), and lacking interfemoral scales (vs 18-19); from C. hitihamii Karunarathna, Poyakov, de Silva et al., 2019b in being smaller SVL $25.3 \mathrm{~mm}$ ( $v s 41.7 \mathrm{~mm}$ ) and by having 117-121 ventrals (vs 132-135), 15-17 ventral scale rows (vs 21), 79-83 midbody scale rows (vs 96-99), 119-126 paravertebral granules (vs 143-149), 15-16 lamellae on fourth toe (2122 ), five precloacal pores ( $v s$ absent), and lacking interfemoral scales (vs 24-26); from $C$. kohukumburai Karunarathna, Poyakov, de Silva et al., 2019b by having 117-121 ventrals (vs 131-134), 15-17 ventral scale rows (vs 23), 119-126 paravertebral granules (vs 150-159), 4-5 flank spines ( $v s$ 7-8), 15-16 lamellae on fourth toe (23-25), five precloacal pores (vs absent), and lacking interfemoral scales (vs 25); from C. nilgala Karunarathna, Bauer, de Silva et al., 2019a by having 117-121 ventrals ( $v s 122$ 129), 79-83 midbody scale rows (vs 71-78), 119-126 paravertebral granules (vs 179-187), 15-16 lamellae on fourth toe (17-18), five precloacal pores ( $v s$ absent), and lacking interfemoral scales (vs 14-15); from C. punctata Manamendra-Arachchi, Batuwita \& Pethiyagoda, 2007 by having 117-121 ventrals (vs 129-137), 15-17 ventral scale rows (vs 2029), 79-83 midbody scale rows (vs 71-78), 119126 paravertebral granules (vs 83-91), 4-5 flank spines (vs 11-13), 15-16 lamellae on fourth toe (17-23), five precloacal pores ( $v s$ absent), nine femoral pores (vs 5-7), and lacking interfemoral scales (vs 25-27); from $C$. rajakarunai Wickramasinghe, Vidanapathirana \& Rathnayake, 2016 in being smaller SVL 25.3 $\mathrm{mm}$ (vs $40.2 \mathrm{~mm}$ ) and by having 117-121 ventrals ( $v s$ 146-186), 15-17 ventral scale rows (vs 26-29), 79-83 midbody scale rows (vs 6974), 119-126 paravertebral granules (vs 81-85), 15-16 lamellae on fourth toe (19-22), five precloacal pores ( $v s$ absent), and lacking interfemoral scales ( $v s$ 20-22); and from $C$. rammalensis Vidanapathirana, Rajeev, Wickramasinghe et al., 2014 in being much smaller SVL $25.3 \mathrm{~mm}(v s 53.8 \mathrm{~mm})$ and by having 117-121 ventrals (vs 186-207), 15-17 ventral scale rows (vs 25-28), 79-83 midbody scale rows ( $v s$ 119-131), 94-96 paravertebral granules (vs 83-91), 4-5 flank spines (vs 1113), 15-16 lamellae on fourth toe (12-23), five precloacal pores ( $v s$ absent), nine femoral pores (vs 14-16), and lacking interfemoral scales (vs 19-24).

Unlike the new species, Cnemaspis butewai Karunarathna, Poyakov, de Silva et al., 2019b; C. ingerorum Batuwita, Agarwal \& Bauer, 2019; C. kallima Manamendra-Arachchi, Batuwita \& Pethiyagoda, 2007; C. kandiana (Kelaart, 1852); C. kivulegedarai Karunarathna, Poyakov, de Silva et al., 2019b; C. kotagamai Karunarathna, de Silva, Botejue et al., 2019c; C. menikay Manamendra-Arachchi, Batuwita \& Pethiyagoda, 2007; C. retigalensis Wickramasinghe \& Munindradasa, 2007; $C$. pava Manamendra-Arachchi, Batuwita \& Pethiyagoda, 2007; C. pulchra ManamendraArachchi, Batuwita \& Pethiyagoda, 2007; C. samanalensis Wickramasinghe \& Munindradasa, 2007; C. silvula ManamendraArachchi, Batuwita \& Pethiyagoda, 2007; C. tropidogaster (Boulenger, 1885); C. upendrai Manamendra-Arachchi, Batuwita \& Pethiyagoda, 2007; C. amith ManamendraArachchi, Batuwita \& Pethiyagoda, 2007; C. dissanayakai Karunarathna, de Silva, Madawala et al., 2019c; C. gotaimbarai Karunarathna, Poyakov, de Silva et al., 2019b; C. kawminiae 


\section{Plate 27}

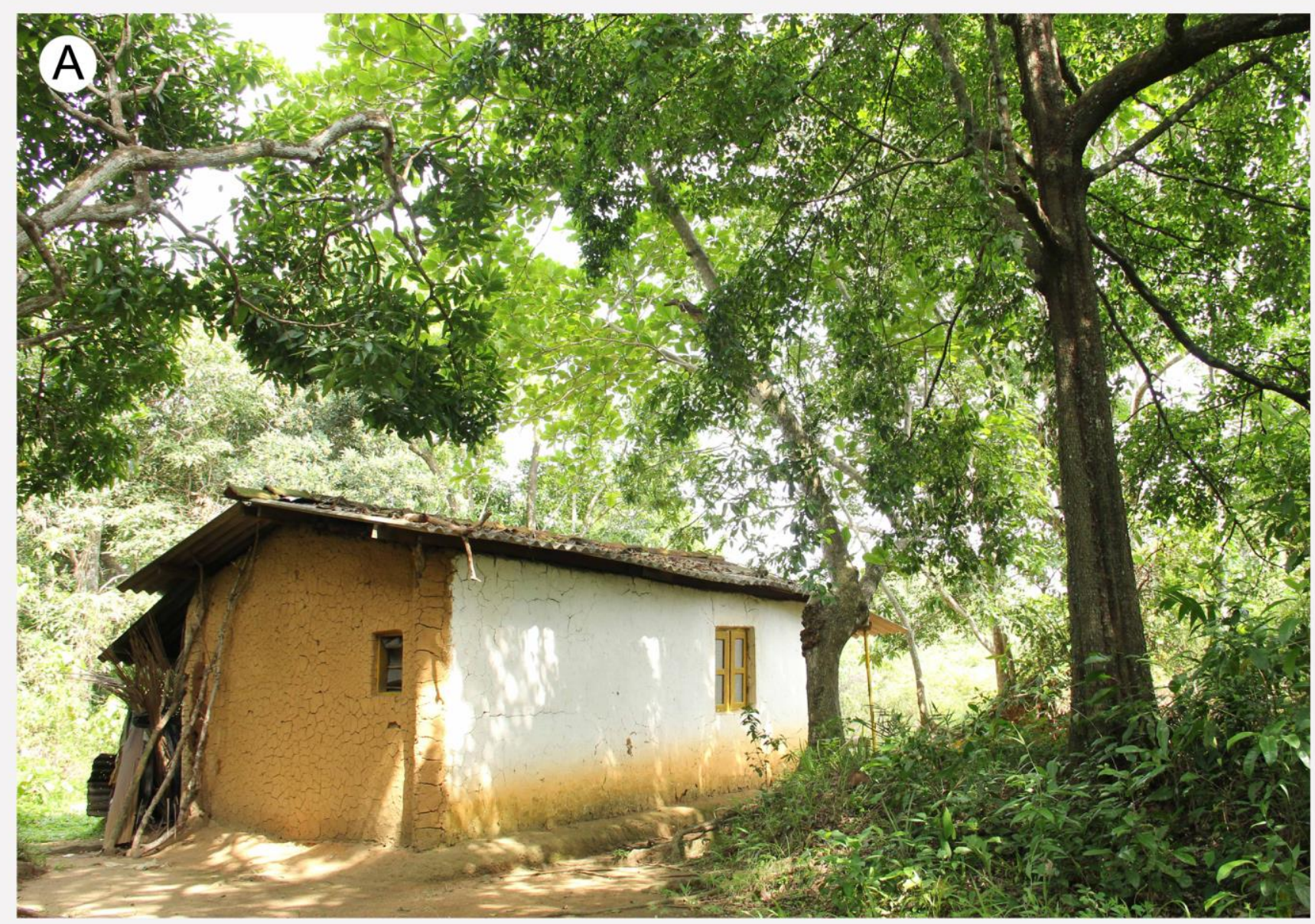

\section{B}

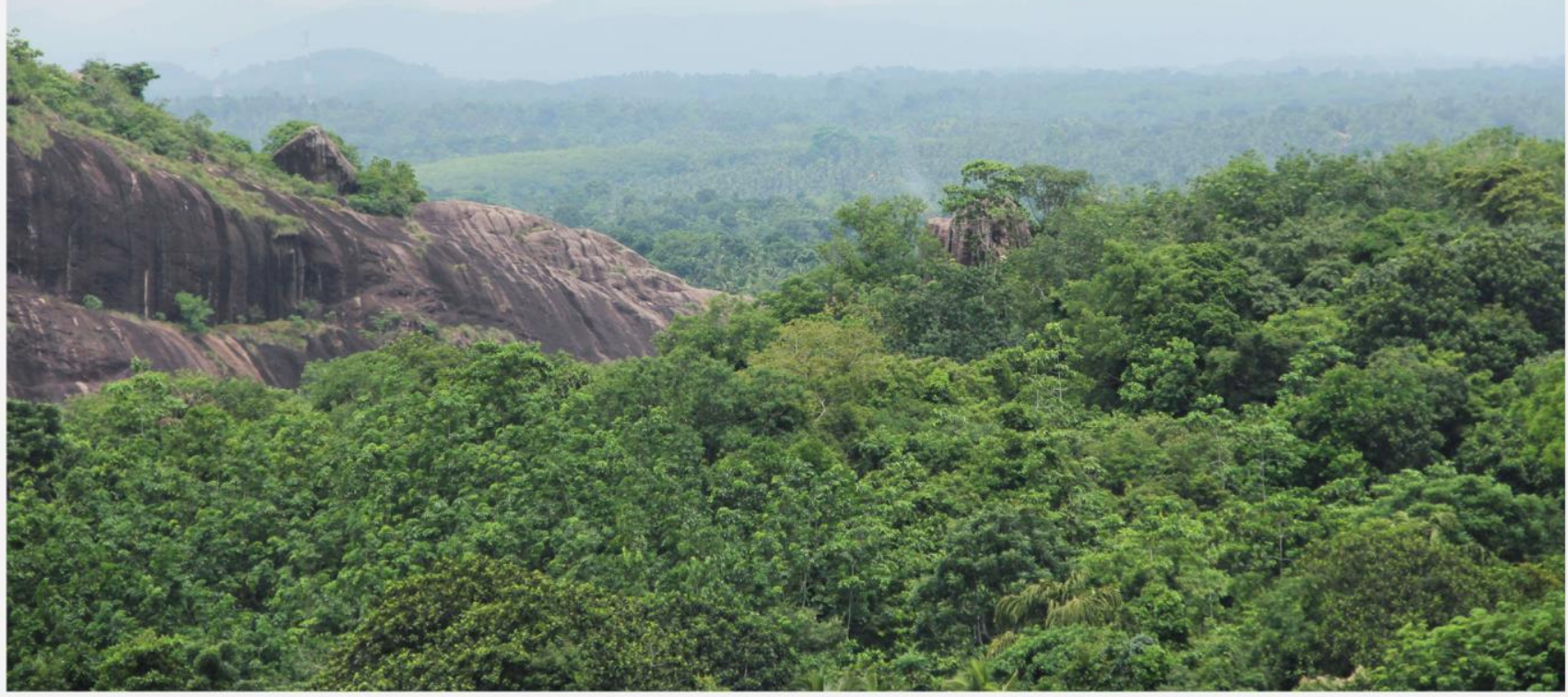

Figure 3. Habitat of Cnemaspis manoae sp. nov. (A) holotype locality, and (B) surrounding forested habitat near the type locality. 


\section{Plate 28}

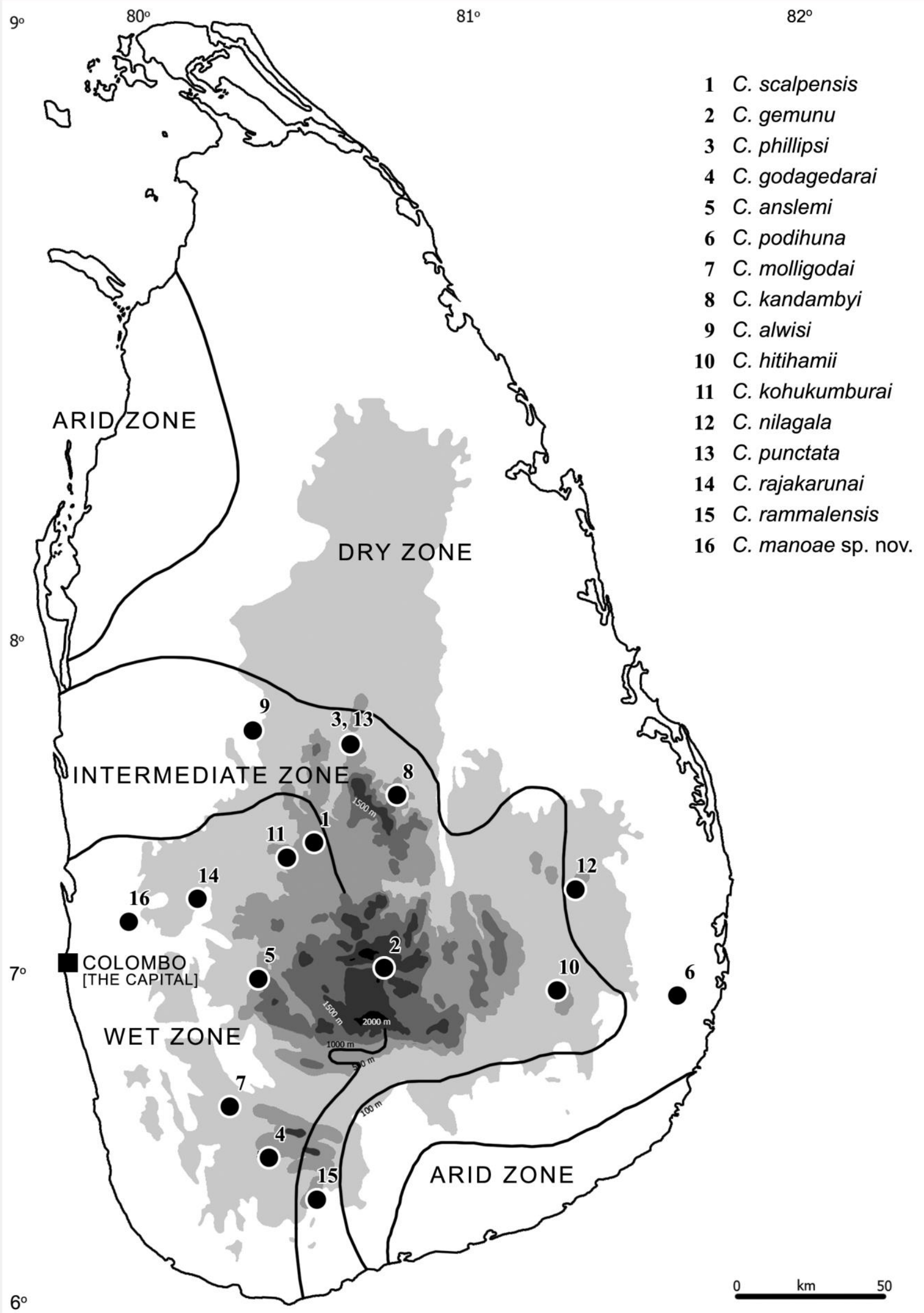

Figure 4. Current distribution map of the Cnemaspis species of the podihuna clade in Sri Lanka; the holotype locality of each species is marked with a circle. 


\section{Plate 29}
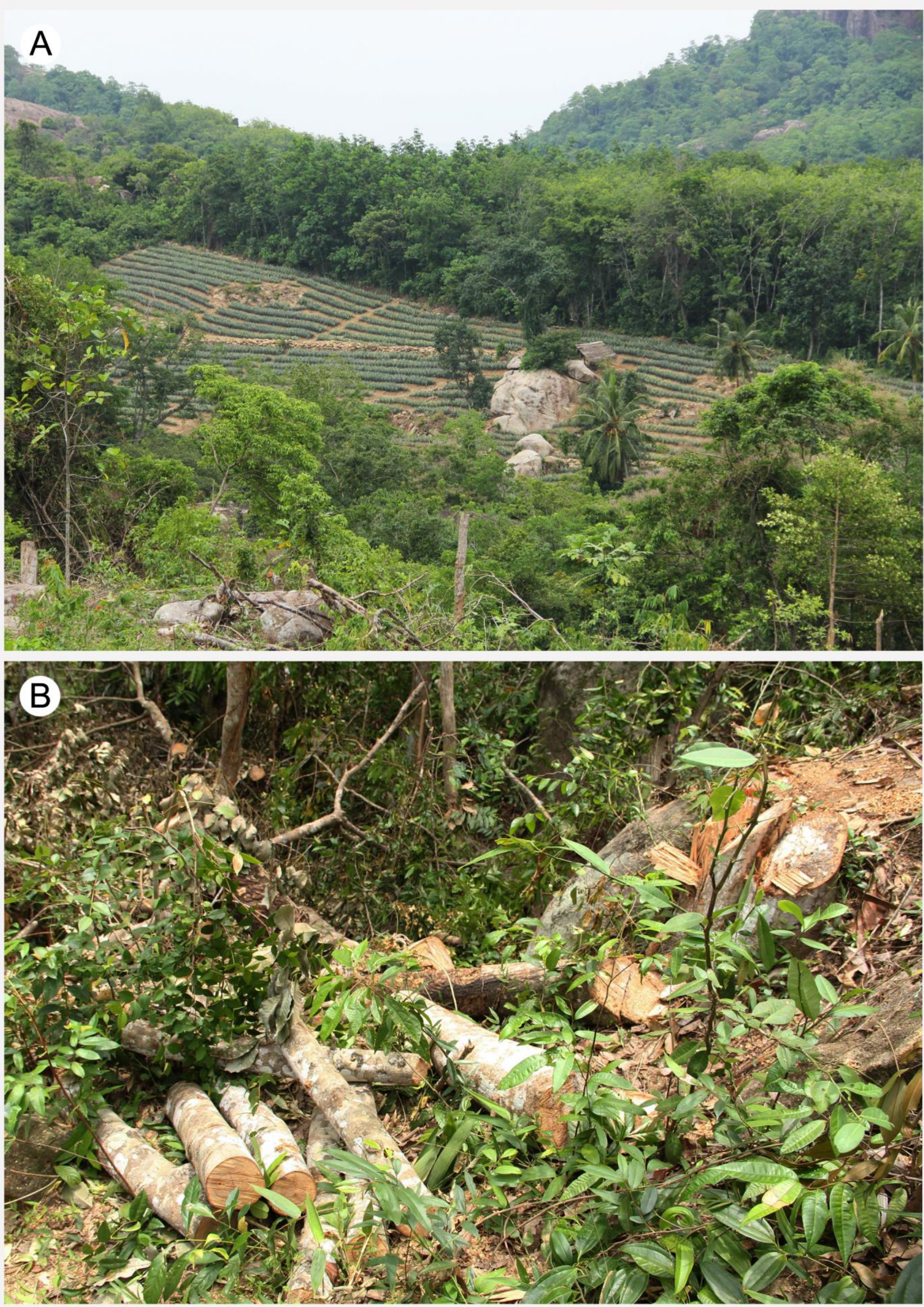

Figure 5. Habitat destruction surrounding the type locality: (A) pineaple plantation invading the natural forest, and (B) illegal logging inside the forest. 
Karunarathna, de Silva, Gabadage et al., 2019c; C. kumarasinghei Wickramasinghe \& Munindradasa, 2007; C. latha ManamendraArachchi, Batuwita \& Pethiyagoda, 2007; and $C$. nandimithrai Karunarathna, Poyakov, de Silva et al., 2019b have no enlarged median subcaudals.

Furthermore, C. butewai, C. ingerorum, $C$. kallima, C. kandiana, C. kivulegedarai, $C$. kotagamai, C. menikay, C. pava, C. pulchra, C. retigalensis, $C$. samanalensis, $C$. silvula, $C$. tropidogaster and $C$. upendrai have heterogeneous dorsal granules ( $v s$ homogeneous in $C$. manoae sp. nov.). Finally $C$. pava, $C$. pulchra, $C$. samanalensis, $C$. silvula, $C$. tropidogaster, and $C$. upendrai have keeled ventral scales ( $v s$ smooth in C. manoae sp. nov.).

Table 2. Diagnostic characters of C. podihuna C. molligodai, C. kandambyi, and C. manoae sp. nov.

\begin{tabular}{lcccc}
\hline Character & $\begin{array}{c}\text { podihuna } \\
(n=4)\end{array}$ & $\begin{array}{c}\text { molligodai } \\
(n=7)\end{array}$ & $\begin{array}{c}\text { kandambyi } \\
(n=2)\end{array}$ & $\begin{array}{c}\text { manoae sp. nov } \\
(n=3)\end{array}$ \\
\cline { 2 - 5 } maximum SVL & 24.7 & 29.0 & 23.6 & 25.3 \\
No. of ventrals & $111-118$ & $127-135$ & $128-137$ & $117-121$ \\
No. of midbody scale rows & $79-83$ & $73-82$ & $71-77$ & $79-83$ \\
No. of paravertebral granules & $102-106$ & $76-83$ & $85-92$ & $119-126$ \\
No. of precloacal pores in males & 3,4 & 4,5 & 3,4 & 5 \\
No. of femoral pores in males & $3-6$ & 8,9 & 5,6 & 9 \\
No. of lamellae on fourth toe & 18,19 & $19-23$ & 19,20 & 15,16 \\
Coloration of vertebral column & bright yellow & light gray with & light gray with & bright yellow \\
(in life) & blotches & dark blotches & dark blitches & stripe \\
Coloration of ventral tail (in life) & white & pale yellow & white & bright yellow \\
Coloration of dorsal tail (in life) & brownish gray & brown & brownish gray & pale yellow \\
Black stripe on dorsal neck (in life) & absent & presnt & absent & present \\
Body shape (in life) & robust \& short & slender \& long & robust \& short & slender \& long \\
\hline
\end{tabular}

\section{Discussion}

During museum reference work at NMSL in 2015, the authors found some specimens collected from Pilikuttuwa $\left(7^{\circ} 03^{\prime} 28.14^{\prime \prime} \mathrm{N}\right.$, $80^{\circ} 02^{\prime} 53.18^{\prime \prime}$ E), Gampaha District, Western Province. These decade old specimens were provisionally identified as three species: Cnemaspis tropidogaster (6 specimens), $C$. alwisi (3 specimens) and C. molligodai (3 specimens). Afterwards one of us (SK) visited the specimen locality in Pilikuttuwa as well as other adjacent localities, Maligatenna $\left(7^{\circ} 04^{\prime} 04.46^{\prime \prime} \mathrm{N}, 80^{\circ} 03^{\prime} 50.11^{\prime \prime} \mathrm{E}\right)$ and Vaarana $\left(7^{\circ} 06^{\prime} 12.64^{\prime \prime} \mathrm{N}, 80^{\circ} 04^{\prime} 27.73^{\prime \prime} \mathrm{E}\right)$, also in the Gampaha District, Western Province to investigate any resident populations. During that visit all three species were discovered living sympatrically. One species (based on above NMSL specimens, Appendix I) was properly documented with the rediscovery of the extant population of $C$. tropidogaster after 120 years from its last record (see Amarasinghe et al. 2016). Later in 2019, we revisited the NMSL collection to re-examine the specimens of the other two species which were previously identified as $C$. alwisi and $C$. molligodai. Although Amarasinghe et al. (2016) noted the peculiarity of finding Cnemaspis molligodai from low altitudes of the wet zone, they had not hitherto compared them to the types of all Sri Lankan Cnemaspis. Therefore, after a thorough examination, here we sought to compare those specimens to confirm their identity. Upon closer examination, it was clear that these specimens included a distinct unnamed species belonging to the podihuna group within the podihuna clade, described herein as a new species. Based on our observations at the type locality, it is evident that the populations have distinct life history strategies, suggesting that we may expect to find more populations restricted to protected forest patches near the Sri Lankan capital of Colombo.

Given the recent studies on Cnemaspis in Sri Lanka, we believe it likely that many more species will ultimately be discovered, especially from the biogeographic regions where Cnemaspis species have not yet been recorded. Based on previous studies, Cnemaspis is known for its tendency to occupy various habitats, with some species frequenting caves, rock crevices, tree bark, claywalls and others foraging in leaf litter, or on tree trunks. Many species occur in the mid elevations (400-600 $\mathrm{m}$ a.s.1.), but some are restricted to highlands or montane areas, and some are isolated to wet forest patches in the lowland dryzone. Although Cnemaspis species occur in a diversity of disturbance regimes 
ranging from secondary forest to primary forest habitats, most of the Sri Lankan species have been recorded only from habitats with well shaded vegetation and minimal disturbance.

In Sri Lanka, 37 Cnemaspis species brings the total number of geckos recorded in the country to 59 species. Among Sri Lankan gekkonids, $83 \%$ (49 species) are endemic to the island, most of which are restricted to the wet zone (> 2,000 $\mathrm{mm}$ of annual average rainfall). Unfortunately, 18 species (30\%) are Critically Endangered (CR), 14 species (23\%) are Endagered (EN), 7 species (11\%) are Vulnerable (VU), and 2 species (3\%) are Data Deficient (IUCN, 2020). However, as our study demonstrated, Sri Lanka's Cnemaspis diversity is not limited to the southwestern lowlands or to the central massif, but is scattered throughout multiple bioclimatic zones and floristic regions, which suggests intricate biogeographic patterns possibly due to multiple colonizations from the Indian mainland rather than a singular event of insular radiation (see Agarwal et al. 2017, Karunarathna et al. 2019b). Thus, continuation of faunal surveys and detailed examination of morphological as well as genetic diagnostic features is critical in revealing the true Cnemaspis diversity in Sri Lanka. Such studies should be focused on the habitats dispersed in isolated hills, fragmented forest patches, rock outcrops, and granite caves, including historical tunnel systems (Karunarathna et al. 2019a-c).

In the present paper, we contribute to the developing understanding of the Cnemaspis species of the podihuna clade by describing a new species from the lowland wet zone $(52 \mathrm{~m}$ a.s.l.). Notably $C$. molligodai (from Waratalgoda, $387 \mathrm{~m}$ a.s.l.) also occurs in the lowland wet zone, and the other previous species of this complex were described from the lowland dry zone (C. podihuna at Lahugala, $25 \mathrm{~m}$ a.s.l.) and the Knuckles submontane forests $(C$. kandambyi from Meemure, $450 \mathrm{~m}$ a.s.l.). The current distribution pattern of the podihuna group shows that the species are distributed in most biogeographic regions (Fig. 6), along with other groups within the podihuna clade (see Fig. 4 and Table 3 ).

Table 3. Current distribution patterns of the Cnemaspis species of podihuna clade in each biogeographic region, "-_" not recorded yet.

\begin{tabular}{|c|c|c|c|}
\hline \multirow{2}{*}{ Biogeographic region (alt. range a.s.1.) } & \multicolumn{3}{|c|}{ podihuna clade } \\
\hline & scalpensis group & podihuna group & alwisi group \\
\hline \multicolumn{4}{|l|}{ (1). Wet Zone } \\
\hline Lowland (0-400 m) & - & $\begin{array}{l}\text { C. molligodai } \\
\text { C. manoae sp. nov. }\end{array}$ & C. rajakarunai \\
\hline Rakwana hills (above 400 m) & C. godagedarai & - & - \\
\hline Central highland submontane $(400-900 \mathrm{~m})$ & $\begin{array}{l}\text { C. scalpensis } \\
\text { C. anslemi }\end{array}$ & - & C. kohukumburai \\
\hline Central highlands montane (above $900 \mathrm{~m}$ ) & C. gетипи & - & - \\
\hline \multicolumn{4}{|l|}{ (2). Intermediate Zone } \\
\hline Lowland $(0-300 \mathrm{~m})$ & - & - & $\begin{array}{c}\text { C. alwisi } \\
\text { C. hitihamii }\end{array}$ \\
\hline Rakwana hills (300-900 m) & - & - & C. rammalensis \\
\hline Uwa/Sabaragamuwa hills (300-900 m) & - & - & - \\
\hline Central highlands (above $900 \mathrm{~m}$ ) & - & - & - \\
\hline Knuckles submontane (300-900 m) & C. phillipsi & C. kandambyi & C. punctata \\
\hline Knuckles montane (above 900 m) & - & - & - \\
\hline \multicolumn{4}{|l|}{ (3). Dry Zone } \\
\hline Lowland (0-300 m) & - & C. podihuna & C. nilgala \\
\hline
\end{tabular}

Cnemaspis hitihami (sic) was described by Karunarathna, Poyakov, de Silva et al. (2019b) who assigned the specific epithet "hitihami", an eponym, as a noun in the genitive case, but without adding the suffix $[-i]$ to the stem of modern personal name, in a case if the personal name is that of a man. However according to the etymology stated the species epithet was formed latinized in case of a man: "Hitihami". Therefore the epithet "hitihami" used by Karunarathna et al. (2019b), is erroneous, and the correct epithet would be "hitihamii", adding the suffix [-i]. 


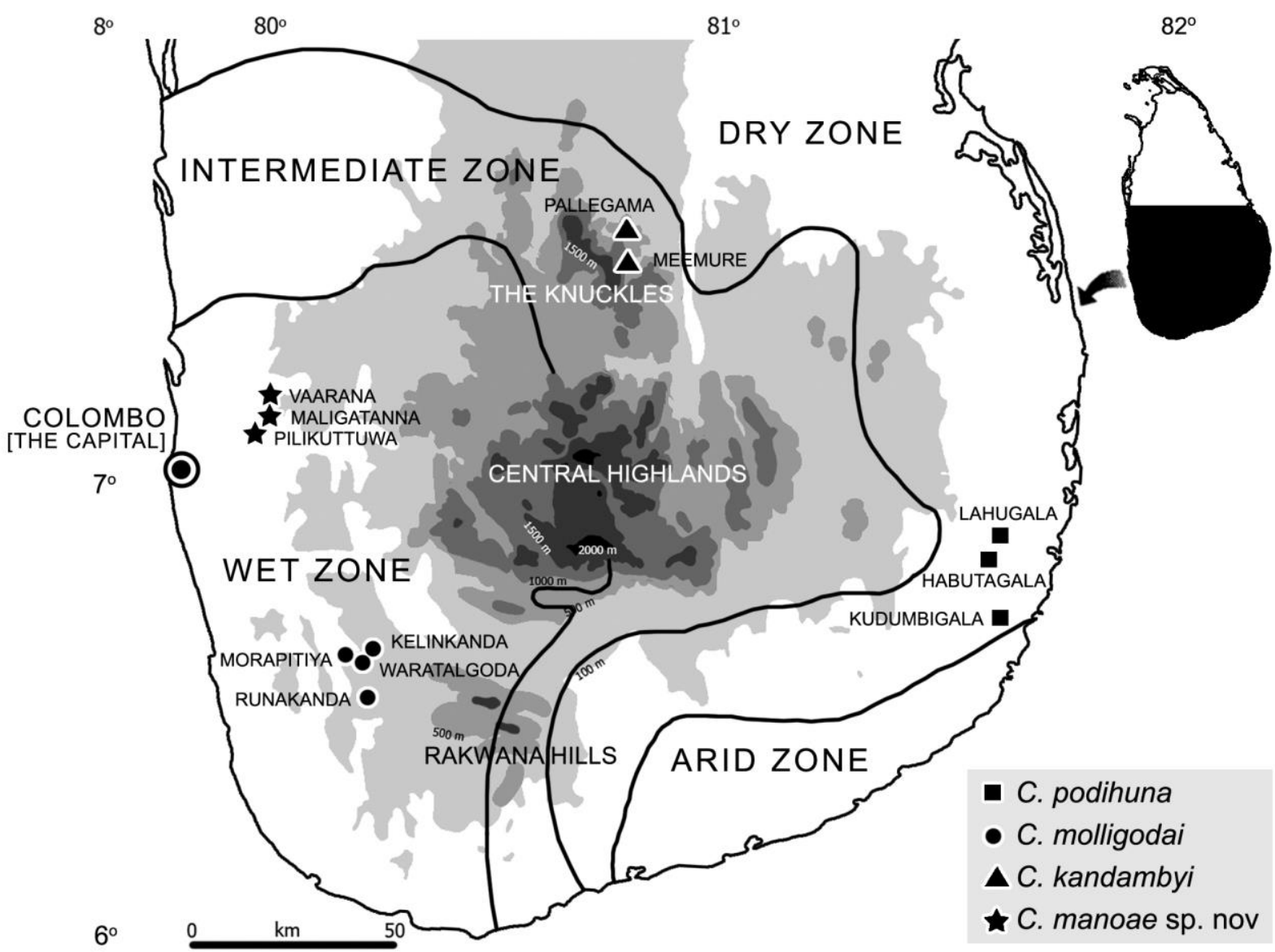

Figure 6. Current distribution map of the Cnemaspis species of the podihuna clade in Sri Lanka

Key to diminutive day geckos of the genus Cnemaspis in Sri Lanka.

1. (a) Subcaudals not enlarged ....................... 2 (kandiana clade)

(b) Subcuadals enlarged .................. 22 (podihuna clade)

2. (a) Dorsal granules homogeneous (kumarasinghei gr

(b) Dorsal granules heterogenrous 8

3. (a) Gular scales smooth ... 4

(b) Gular scales keeled C. amith

4. (a) Paravertebral granules 61-79 5

(b) Paravertebral granules 86-99 ................... 6

(c) Paravertebral granules 105-121 7

5. (a) Ventrals 109-115, midbody scales 69-73 ...... (b) Ventrals 120-134, midbody scales 87-94 ....... . C. kumarasinghei

6. (a) Lamellae on fourth toe 15 or 16 , midbody scales 76-78

C. kawminiae (b) Lamellae on fourth toe 19-20, midbody scales $87-89$

C. nandimithrai
7. (a) Midbody scales 72-79, lamellae on fourth toe 19 or 20, ventrals 129-138 ........ C. gotaimbarai (b) Midbody scales 94-98, lamellae on fourth toe 21 or 22 , ventrals $118-120$........ C. dissanayakai

8. (a) Pectoral and abdominal scales smooth ........ 9 (kandiana group)

(b) Pectoral and abdominal scales keeled ........ 16 (tropidogaster group)

9. (a) Gular scales smooth ............................ 10

(b) Gular scales keeled ............................ 13

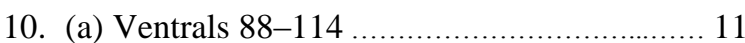

(b) Ventrals 131-138 ............................... 12

11. (a) Paravertebral granules 93-101, lamellae on fourth toe 17 or 18 , flank spines 7 or 8

C. ingerorum (b) Paravertebral granules 131-133, lamellae on fourth toe 14-16, flank spines 4 or 5 .....

C. kivulegedarai

12. (a) Flank spines 6 or 7 , one precloacal pore (in males), paravertebral granules 114-119, midbody scales 79-84 ................ C. kotagamai (b) Flank spines $12-15,3$ or 4 precloacal pores (in males), paravertebral granules 99-107, midbody scales $67-74$ C. kallima 
13. (a) Midbody scales 68-79, paravertebral granules 82-99 ...................................... 14 (b) Midbody scales 92-98, paravertebral granules $134-138$ C. butewai

14. (a) Flank spines 4-7 15

(b) Flank spines 13-15 C. menikay

15. (a) One precloacal pore (in males)

(b) 2-4 precloacal pores (in males) C. retigalensis C. kandiana

16. (a) Paravertebral granules $83-113$ 17

(b) Paravertebral granules 64-72

.. C. samanalensis

17. (a) Flank spines 5-7 18

(b) Flank spines 9-15 19

18. (a) Midbody scales $67-73$ (b) Midbody scales 92-98 C. pulchra

9. (a) Paravertebral granules 83-113 C. tropidogaster

(b) Paravertebral granules 64-72 20

C. samanalensis

20. (a) Ventrals 132-145 21 (b) Ventrals 112-128 C. upendrai

21. (a) Paravertebral granules 83-98 C. pava

(b) Paravertebral granules 102-113 C. silvula

22. (a) Precloacal pores present (in males) 23 (podihuna group)

(b) Precloacal pores absent (in males) ............. 26 (scalpensis + alwisi groups)

23. (a) Ventrals 111-121, paravertebral granules 102-126, lamellae on fourth toe 15-19 ........ 24 (b) Ventrals 127-137, paravertebral granules 7692, lamellae on fourth toe 19-23 .. 25

24. (a) Paravertebral granules $102-106,3$ or 4 precloacal pores (in males), 3-6 femoral pores (in males), lamellae on fourth toe 18 or 19

C. podihuna

(b) Paravertebral granules 119-126, 5 precloacal pores (in males), 9 femoral pores (in males), lamellae on fourth toe 15 or 16

C. manoae sp. nov.

25. (a) Paravertebral granules $76-83,8$ or 9 femoral pores (in males) C. molligodai (b) Paravertebral granules 85-92, 5 or 6 precloacal pores (in males) C. kandambyi

26. (a) Midbody scales 69-102 27

(b) Midbody scales 119-131 ...... C. rammalensis (alwisi group)
27. (a) Femoral pores $11-16$ (in males) ............... 28 (scalpensis group)

(b) Femoral pores 5-10 (in males) ................. 32 (alwisi group)

28. (a) Paravertebral granules 79-93, lamellae on fourth toe 17-19 .................................... 29 (b) Paravertebral granules 101-122, lamellae on

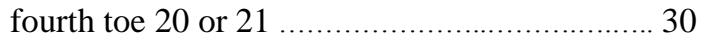

29. (a) Ventrals 112-118, flank spines 7 or $8,11-14$ femoral pores (in males) .................. C. gemunu (b) Ventrals 128-143, flank spines 4-6, 15 or 16 femoral pores (in males) .................. C. phillipsi

30. (a) Paravertebral granules 102-112, ventrals 120-137 ................................................ 31

(b) Paravertebral granules 118-122, ventrals 111-117 ........................................ C. anslemi

31. (a) Midbody scales 81-89, flank spines 9-11, ventrals 120-131 ....................... C. scalpensis (b) Midbody scales $98-102$, flank spines 5 or 6 , ventrals 133-137 C. godagedarai

32. (a) Flank spines 3-8 33

(b) Flank spines 11-13 C. punctata

33. (a) Paravertebral granules 81-97, ventrals 145-

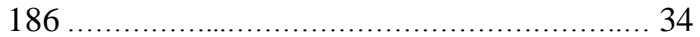
(b) Paravertebral granules 143-187, ventrals 122-135 ................................................ 35

34. (a) Paravertebral granules $81-85$
(b) Paravertebral granules 89-97
C. rajakarunai C. alwisi

35. (a) Lamellae on fourth toe 21-25, paravertebral granules 143-159, midbody scales 81-99, ventrals $131-135$........................................ 36 (b) Lamellae on fourth toe 17 or 18 , paravertebral granules $179-187$, midbody scales 71-78, ventrals $122-129$................. C. nilgala

36. (a) Midbody scales $81-88$, flank spines 7 or 8 , paravertebral granules 150-159, lamellae on fourth toe 23-25 .................. C. kohukumburai (b) Midbody scales 96-99, flank spines 4 or 5, paravertebral granules 143-149, lamellae on fourth toe 21 or 22 C. hitihamii

\section{Acknowledgments}

We thank Aaron Bauer (Villanova University, USA), Lee Grismer (La Sierra University, USA) and an anonymous reviewer for the review of the manuscript and critical comments. Nanda Wickramasinghe (former director), Sanuja Kasthuriarachchi (director), Lankani Somaratne, Chandrika Munasinghe, Rasika Dasanayake, 
Ravindra Wickramanayake, and P. Gunasiri at NMSL are acknowledged for facilitating the inhouse study of specimens under their care. Also we thank Anslem de Silva, Kanishka Ukuwela, Nirmala Perera, Majintha Madawala, Hiranya Sudasinghe, Dinesh Gabadage, Madhava Botejue, Gayan Edirisinghe, Sulakshana Wickramarachchi, Hasantha Wijethunga and Niranjan Karunarathna for providing valuable assistance in numerous stages of the study. Finally, we thank J. Supriatna and the staff of the Research Center for Climate Change, University of Indonesia, for their support.

\section{Literature cited}

Agarwal, I., S. Biswas, A.M. Bauer, E. Greenbaum, T.R. Jackman et al. (2017) Cryptic species, taxonomic inflation, or a bit of both? New species phenomenon in Sri Lanka as suggested by a phylogeny of dwarf geckos (Reptilia, Squamata, Gekkonidae, Cnemaspis). Systematics and Biodiversity, 15 (5): 1-13.

Amarasinghe, A.A.T. and A.M. Bauer (2009). On the holotype of Cnemaspis podihuna Deraniyagala, 1944. Taprobanica, 1: 80-82.

Amarasinghe, A.A.T. and P.D. Campbell (2016). On the rediscovery of the Cnemaspis podihuna Deraniyagala, 1944 (Reptilia: Gekkonidae) holotype at the Natural History Museum, London. Zootaxa, 4137 (2): 296-300.

Amarasinghe, A.A.T., M.B. Harvey, A. Riyanto, and E.N. Smith (2015). A new species of Cnemaspis (Reptilia: Gekkonidae) from Sumatra, Indonesia. Herpetologica, 71 (2): 160-167.

Amarasinghe, A.A.T., P.D. Campbell, M.B. Madawala, W.M.S. Botejue, D.E. Gabadage et al. (2016). The redescovery of live population of Cnemaspis tropidogaster (Boulenger, 1885) (Sauria: Gekkonidae) from Sri Lanka after 120 years. Zootaxa, 4200 (3), 395-405.

Batuwita, S. and S. Udugampala (2017). Description of a new species of Cnemaspis (Squamata: Gekkonidae) from Knuckles Range of Sri Lanka. Zootaxa, 4254 (1): 82-90.

Batuwita, S., I. Agarwal, and A.M. Bauer (2019). Description of a new diminutive, rupicolous species of day-gecko (Squamata: Gekkonidae: Cnemaspis) from southern Sri Lanka. Zootaxa, 4565 (2): 223-234.

Bauer, A.M., A. de Silva, E. Greenbaum, and T. Jackman (2007). A new species of day gecko from high elevation in Sri Lanka, with a preliminary phylogeny of Sri Lankan Cnemaspis (Reptilia: Squamata: Gekkonidae).
Mitteilungen aus dem Museum für Naturkunde, Berlin, Zoologische Reihe, 83 (1): 22-32.

Boulenger, G.A. (1885). Catalogue of the Lizards in the British Museum (Natural History). British Museum (Natural History), London: $436 \mathrm{pp}$.

Deraniyagala, P.E.P. (1944). A new Cnemaspis gecko from Ceylon. Journal of Royal Asiatic Society Sri Lanka, 97 (2): 226-227.

de Silva, A., A.M. Bauer, M. Botejue, and S. Karunarathna (2019). A new species of endemic day gecko (Reptilia: Gekkonidae: Cnemaspis) from a wet zone forest in second peneplain of Southern Sri Lanka. Amphibian \& Reptile Conservation, 13 (1): 198-208.

Ferguson, W.M. (1877). Reptile Fauna of Ceylon. Letter on a collection sent to the Colombo Museum. William Henry Herbert, Government Printer, Colombo: 42 pp.

Gunatileke, I.A.U.N. and C.V.S. Gunatileke (1990). Distribution of floristic richness and its conservation in Sri Lanka. Conservation Biology, 4 (1): 21-31.

ICZN (1999). International Code of Zoological Nomenclature, $4^{\text {th }}$ edition. International Trust for Zoological Nomenclature, London, UK: $306 \mathrm{pp}$.

IUCN Standards and Petitions Committee (2019). Guidelines for using the IUCN Red List categories and criteria version 14. Geneva, Switzerland. Prepared by the Standards and Petitions Committee: 113 pp.

IUCN, 2020. Assess to Plan: Conservation Action Planning for the Snakes and Lizards of Sri Lanka. Gibson, C., A. de Silva, M.F. Tognelli, and S. Karunarathna (eds.). IUCN Conservation Planning Specialist Group, Apple Valley, MN, USA.

Karunarathna, D.M.S.S., A.A.T. Amarasinghe, U.T.I. Abeywardena, M.D.C. Asela, H.B. Jayaneththi et al. (2011). Some observations of Cnemaspis podihuna Deraniyagala, 1944 (Reptilia: Gekkonidae) in Sri Lanka. Gekko, 6 (1): 23-29.

Karunarathna, S., A. Bauer, A. de Silva, T. Surasinghe, L. Somaratna et al. (2019a). Description of a new species of the genus Cnemaspis Strauch, 1887 (Reptilia: Squamata: Gekkonidae) from the Nilgala Savannah forest, Uva Province of Sri Lanka. Zootaxa, 4545 (3): 389-407.

Karunarathna, S., N.A. Poyarkov, A. de Silva, M. Madawala, M. Botejue et al. (2019b). Integrative taxonomy reveals six new species of day geckos of the genus Cnemaspis Strauch, 1887 (Reptilia: Squamata: 
Gekkonidae) from geographically-isolated hill forests in Sri Lanka. Vertebrate Zoology, 69 (3): 247-298.

Karunarathna, S., A. de Silva, M. Botejue, D. Gabadage, L. Somaratna et al. (2019c). Three new species of day geckos (Reptilia: Gekkonidae: Cnemaspis Strauch, 1887) from isolated granite cave habitats in Sri Lanka. Amphibian \& Reptile Conservation, 13 (2): 323-354.

Karunarathna, S. and K. Ukuwela (2019). A new species of dwarf day gecko (Reptilia: Gekkonidae: Cnemaspis) from lowerelevations of Samanala Nature Reserve in Central Massif, Sri Lanka. Amphibian \& Reptile Conservation, 13 (2): 14-27.

Kelaart, E.F. (1852). Prodromus Faunae Zeylanicae, being contributions to the zoology of Ceylon. volume 1. published by the author, Colombo: $197 \mathrm{pp}$.

Manamendra-Arachchi, K., S. Batuwita, and R. Pethiyagoda (2007). A taxonomic revision of the Sri Lankan day geckos (Reptilia: Gekkonidae: Cnemaspis), with description of new species from Sri Lanka and southern India. Zeylanica, 7 (1): 9-122.

Strauch, A. (1887). Bermerkungen über die Geckonidensammlung im zoologischen Museum der Kaiserlichen Akademie der Wissenschaften zu St. Petersburg. Mémoires de l'Académie Impériale des Sciences de St. Pétersbourg, 35 (7): 1-72.
Uetz, P., S. Cherikh, G. Shea, I. Ineich, P.D. Campbell et al. (2019). A global catalog of primary reptile type specimens. Zootaxa, 4695 (5): 438-450.

Vidanapathirana, D.R., M.D.G. Rajeev, N. Wickramasinghe, S.S. Fernando, and L.J.M. Wickramasinghe (2014). Cnemaspis rammalensis sp. nov., Sri Lanka's largest daygecko (Sauria: Gekkonidae: Cnemaspis) from Rammalakanda Man and Biosphere Reserve in southern Sri Lanka. Zootaxa, 3755 (3): 273286.

Wickramasinghe, L.J.M. (2006). A new species of Cnemaspis (Sauria: Gekkonidae) from Sri Lanka. Zootaxa, 1369: 19-33.

Wickramasinghe, L.J.M. and D.A.I. Munindradasa (2007). Review of the genus Cnemaspis Strauch, 1887 (Sauria: Gekkonidae) in Sri Lanka with the description of five new species. Zootaxa, 1490: 1-63.

Wickramasinghe, L.J.M., D.R. Vidanapathirana, and R.M.G.P. Rathnayake (2016). Cnemaspis rajakarunai sp. nov., a rock dwelling daygecko (Sauria: Gekkonidae: Cnemaspis) from Salgala, an unprotected lowland rainforest in Sri Lanka. Zootaxa, 4168 (1): 92-108.

Appendix I. Other specimens examined

Cnemaspis alwisi (13 ex.): Sri Lanka: NMSL 2004.09.01 (holotype), 2004.09.02-03 (paratypes), WHT 5918, 6518-9, 7336-8, 7343-6.

C. anslemi (3 ex.): Sri Lanka: NMSL 2019.14.01 (holotype), 2019.14.02-03 (paratypes).

C. gemunu (9 ex.): Sri Lanka: AMB 7495 (holotype), 7507 (paratype), WHT 7221, 7347-8, NMSL 2006.11.01-04.

C. godagedarai (3 ex.): Sri Lanka: NMSL 2019.09.01 (holotype), 2019.16.01-02 (paratypes).

C. hitihamii (3 ex.): Sri Lanka: NMSL 2019.06.01 (holotype), 2019.06.02-03 (paratypes).

C. kandambyi (2 ex.): Sri Lanka: WHT 9466 (holotype), 9467 (paratype).

C. kohukumburai (3 ex.): Sri Lanka: NMSL 2019.05.01 (holotype), 2019.05.02-03 (paratypes).

C. molligodai (7 ex.): Sri Lanka: NMSL 2006.14.01 (holotype), 2006.14.02-05 (paratypes), NMSL uncat. (2 specimens)

C. nilgala (4 ex.): Sri Lanka: NMSL 2018.07.01 (holotype), 2018.06.01-03 (paratypes).

C. phillipsi (4 ex.): Sri Lanka: WHT 7248 (holotype), 7236-8 (paratypes).

C. podihuna (4 ex.): Sri Lanka: BMNH 1946.8.1.20 (holotype), NMSL 2006.10.02-04.

C. punctata (5 ex.): Sri Lanka: WHT 7256 (holotype), 7223 (paratype), 7226 (paratype), 7243-4 (paratypes).

C. rajakarunai (3 ex.): Sri Lanka: NMSL 2016.07.01 (holotype), DWC 2016.05.01-02 (paratypes).

C. rammalensis (2 ex.): Sri Lanka: NMSL 2013.25.01 (holotype), DWC 2013.05.001.

C. scalpensis (11 ex.): Sri Lanka: NMSL 2004.01.01 (neotype), 2004.02.01, 2004.03.01, 2004.04.01, WHT 7265, 7268-9, 7274-6, 7320.

C. tropidogaster (7 ex.): Sri Lanka: BMNH 71.12.14.49 (lectotype), NMSL 5151-2, 5157, 5159, 5970, 5974. 